\title{
Bacterial community characteristics and enzyme activities in Imperata cylindrica litter as phytoremediation progresses in a copper tailings dam
}

\author{
Tong Jia ${ }^{\text {Corresp., Equal first author, } 1 \text {, Tingyan Guo }}{ }^{\text {Equal first author, } 1 \text {, Baofeng Chai }}{ }^{1}$ \\ ${ }^{1}$ Shanxi Key Laboratory of Ecological Restoration on Loess Plateau, Institute of Loess Plateau, Shanxi University, Taiyuan, China \\ Corresponding Author: Tong Jia \\ Email address: jiatong@sxu.edu.cn
}

This study analy zed Imperata cylindrica litter to determine variation in bacterial community composition and function along with enzyme activity as phytoremediation progresses. We found significant differences in physical and chemical properties of soil and litter in the different sub-dams investigated. The Actinobacteria, Gammaproteobacteria and Alphaproteobacteria were the dominant bacteria found in the litter of the different sub-dams. The alpha diversity ( $\alpha$-diversity) of litter bacterial community increased over as phytoremediation progressed, while total soil carbon and total litter carbon content were positively correlated to bacterial $\alpha$-diversity. Total litter carbon and total nitrogen were the key factors that influenced bacterial community structure. Heavy metal can influence the degradation of litters by altering the composition of the microbial community.

Furthermore, bacterial communities encoded with alpha-amylase ( $\alpha$-amylase) dominated during the initial phytoremediation stage; however, bacterial communities encoded with hemicellulase and peroxidase gradually dominated as phytoremediation progressed.

Findings from this study provide a basis for exploring litter decomposition mechanisms in degraded ecosystems, which is critically important to understand the circulation of substances in copper tailings dams. 


\section{Bacterial community characteristics and enzyme}

2 activities in Imperata cylindrica litter as

3 phytoremediation progresses in a copper tailings dam

4 Tong Jia ${ }^{\dagger}$, Tingyan $\mathrm{Guo}^{\dagger}$, Baofeng Chai

5 Shanxi Key Laboratory of Ecological Restoration on Loess Plateau, Institute of Loess Plateau,

6 Shanxi University, Taiyuan, China

$7 \dagger$ These authors contributed equally to this work.

8 Corresponding Author:

9 Tong Jia

10 No. 92 Wucheng Road, Xiaodian district, Taiyuan, Shanxi 030006, P.R. China.

11 Email address: jiatong@sxu.edu.cn

12

\section{Abstract}

This study analyzed Imperata cylindrica litter to determine variation in bacterial community composition and function along with enzyme activity as phytoremediation progresses. We found significant differences in physical and chemical properties of soil and litter in the different subdams investigated. The Actinobacteria, Gammaproteobacteria and Alphaproteobacteria were the dominant bacteria found in the litter of the different sub-dams. The alpha diversity ( $\alpha$-diversity) of litter bacterial community increased over as phytoremediation progressed, while total soil carbon and total litter carbon content were positively correlated to bacterial $\alpha$-diversity. Total litter carbon and total nitrogen were the key factors that influenced bacterial community structure. Heavy metal can influence the degradation of litters by altering the composition of the microbial community. Furthermore, bacterial communities encoded with alpha-amylase ( $\alpha$ amylase) dominated during the initial phytoremediation stage; however, bacterial communities encoded with hemicellulase and peroxidase gradually dominated as phytoremediation progressed. Findings from this study provide a basis for exploring litter decomposition mechanisms in degraded ecosystems, which is critically important to understand the circulation of substances in copper tailings dams.

\section{Introduction}

Although mineral resources are the foundation of economic development, the long-term exploitation of these resources have caused a series of ecological problems that have in some cases led to the degradation of the ecological environment (Guo \&Wang, 2013). The Northern Copper Mine in the Zhongtiao Mountains of Yuanqu County, Shanxi Province, is one of the seven largest copper mining regions in China (Jia et al., 2018). This copper mine produces over 7 million tons of tailings each year. Long-term mining activities in this region have destroyed its native vegetation (Jia et al., 2017) and have led to severe soil erosion and a serious decline in soil fertility (Jia et al., 2019), which in turn has critically degraded local ecosystems. However, previous studies have found that some plant species, such as Bothriochloa ischaemum and Imperata cylindrica (Jia et al., 2018), colonize copper tailing dams. Of these two species, $I$. cylindrica is dominant in the study region, which produces a large amount of litter at the end of 
40 the growing season. I. cylindrica is the perennial herb, and placed in the family Graminae and 41 Genus Imperata. Their blossom period is from April to June. It is a hardy species, tolerant to 42 shade, high salinity and drought. I. cylindrica is a vigorous, creeping perennial grass with long 43 stolons and rooting at nodes. This grass can adapt easily to a wide range of soils (Paz-Alberto et 44 al., 2007). Litter is the link between vegetation and soil interface, and it plays an important role 45 in the function of aboveground and belowground ecosystems (Bani et al., 2018; Tan et al., 2020). 46 Litter decomposition controls both the material and chemical cycles of terrestrial ecosystems 47 (Cotrufo et al., 2015; Xu et al., 2020). Therefore, exploring litter decomposition characteristics and associated influencing factors in a copper tailing dam will help provide new insight into understanding the crucial role that litter decomposition plays in nutrient cycling in this region.

50

51

52

53

54

55

56

57

58

59

60

61

62

63

64

65

66

67

68

69

70

71

72

73

74

75

76

77

78
Litter decomposition in terrestrial ecosystems is mainly controlled by litter quality, soil properties and biological factors at a local scale (Berg, 2014; Fissore et al., 2016; Keiluweit et al., 2015; Santschi et al., 2018). Among these biological factors, microorganisms are widely known to be the main driving force behind litter decomposition processes (Bani et al. 2018; Zhao et al. 2017). Previous studies determined that fungi are the main decomposers that produce ligninmodifying enzymes (LMEs) and cellulase (Boer et al., 2005; Yu et al., 2017). Recent studies have also shown that soil bacteria can produce cellulase, indicating that bacteria play an important role in litter decomposition processes (Lopez-Mondejar et al., 2016). Additionally, Zhang et al. (2019) found that litter bacteria encoded with beta-glucosidase ( $\beta$-glucosidase) genes may improve the capacity of litter decomposition in coniferous forests. Furthermore, many studies have shown that the relative abundance of litter bacteria increases during later litter decomposition stages, and these bacteria play a crucial role in litter decomposition (Berg, 2014). Therefore, it is scientifically warranted to explore litter bacteria communities and the litter decomposition characteristics, particularly in areas suffering from heavy metal pollution. However, most previous relevant studies on litter were conducted in natural ecosystems. Accordingly, very little is known about litter decomposition mechanisms in degraded copper tailings dam ecosystems.

Microbial extracellular enzymatic activities have garnered much attention, and this is due to the roles they play in litter decomposition (Schimel et al., 2017; Wang et al., 2020). According to litter substrate properties, enzymes are generally classified into cellulase, LMEs, protease and phosphatase (Nakamura et al., 2019; Wang et al., 2006). Litter decomposition is a vital process in the global terrestrial carbon cycle (Bani et al., 2018; Wang et al., 2017; Yan et al., 2018). Litter carbon storage is mainly composed of cellulose and lignin. Therefore, both cellulolytic enzymes and ligninolytic enzymes play a significant role in litter decomposition. Cellulolytic enzymes mainly include endoglucanase, cellobiohydrolase and $\beta$-glucosidase (Fang et al., 2010). Comparatively, the lignin component of litter is the slowest to degrade, whose decomposition mainly depends on ligninolytic enzymes. At present, most studies on ligninolytic enzymes focus on peroxidase, laccase, polyphenol oxidase and catalase (Johnsen \& Jacobsen, 2008; Saiya-Cork et al., 2002). Accordingly, our study explored the relationship between bacterial communities 
80

81

82

83

84

85

86

87

88

89

90

91

92

93

94

95

96

97

98

99

100

101

102

103

104

105

106

107

108

109

110

111

112

113

114

115

116

117

and enzyme activities in litter, which can help us to better understand litter degradation mechanisms.

In this study, we investigate bacterial community characteristics and enzyme activities of $I$. cylindrica litter as phytoremediation progresses, while we elucidate on the main influencing factors in a copper tailings dam. We use high-throughput sequencing and chemical analysis to test the following questions: (1) whether there exist different bacterial community structures as phytoremediation progresses; (2) whether soil and litter properties affect extracellular enzymatic activities and bacterial community characteristics; and (3) whether relevant key factors vary during different phytoremediation stages.

\section{Materials \& Methods}

\section{Site description and soil sampling}

Construction of the Eighteen River tailings of the Northern Copper Mine $\left(35^{\circ} 15^{\prime} \sim 35^{\circ} 17^{\prime} \mathrm{N}\right.$, $118^{\circ} 38^{\prime} \sim 111^{\circ} 39^{\prime} \mathrm{E}$ ) in the southern region of the Zhongtiao Mountains started in 1969. This region is under the influence of a continental monsoon climate. The average annual temperature is $13.5^{\circ} \mathrm{C}$, while the annual precipitation is $631 \mathrm{~mm}$ (Liu et al., 2018a). Currently, the Eighteen River tailings dam is composed of 16 sub-dams (Jia et al., 2019). The main constituents of the dam comprise of copper tailings and artificial loess. The slope ratio of the dam is 1:6.

In April 2019, we collected samples at S516, S536 and S560 sub-dam, and the age of phytoremediation of these three sub-dams was 50 years, 22 years and 5 years respectively. Litter on the soil surface and topsoil samples were collected in the I. cylindrica distribution area of each sub-dam, for which three replications were made for each sub-dam. A total of 18 litter and soil samples were collected. Samples were sealed in self-sealing plastic bags, placed inside boxes containing ice before being immediately transported to the lab. Litter samples were then subdivided into two, one being stored at $-20^{\circ} \mathrm{C}$ for high-throughput sequencing and the other being stored at $4{ }^{\circ} \mathrm{C}$ along with soil samples to determine physiochemical properties. The sterile gloves should be worn throughout the sampling process to avoid contamination of the samples.

\section{Chemical properties and enzyme activities of samples}

Soil water content (SWC) was determined by means of the drying method. An elemental analyzer (vario EL/MACRO cube, Elementar, Hanau, Germany) was used to measure total carbon and nitrogen content in soil (TC_Soil and TN_Soil) and litter (TC_Litter and TN_Litter). Soil $\mathrm{pH}$ was measured by potentiometric method. Shaking in a soil-water $(1: 2.5 \mathrm{w} / \mathrm{v})$ suspension for $30 \mathrm{~min}$ and then rest. Soil particle size (PS) was measured by using Mastersizer 3000 laser diffraction particle size analysis instrument (Malvern Co. Ltd.,Malvern, UK). Soil heavy metals, which include $\mathrm{As}, \mathrm{Cd}, \mathrm{Cu}, \mathrm{Pb}$ and $\mathrm{Zn}$, were measured by Inductively Coupled Plasma-Atomic Emission Spectrometry (iCAP 6000, Thermo Fisher, UK). Potassium permanganate titration was used to measure catalase. 3,5-Dinitrosalicylic acid colorimetry was used to measure sucrase and cellulase, while phenol-sodium hypochlorite colorimetry was used to measure urease. Finally, iodimetry was used to measure polyphenol oxidase (Guan, 1986).

\section{Techniques used for DNA extraction, PCR amplification and Miseq sequencing}


118 We initially washed nine litter samples three times in a sterile phosphate buffer solution (PBS: $119 \mathrm{NaCl}, \mathrm{KCl}, \mathrm{Na}_{2} \mathrm{HPO}_{4}$ and $\left.\mathrm{KH}_{2} \mathrm{PO}_{4}\right)$ before being filtered through a sterile membrane filter $(0.2$ $120 \mu \mathrm{m}$ pore size) (Millipore, Jinteng, Tianjin, China). These membrane with bacteria samples, used 121 to extract microbial DNA, were sealed in sterile centrifuge tubes. The E.Z.N.A. ${ }^{\circledR}$ Soil DNA Kit 122 (Omega Bio-tek, Norcross, GA, USA) was employed for the extraction of microbial plant and 123 soil DNA under the manufacturer's protocol. The NanoDrop ND-1000 UV-Vis 124 Spectrophotometer (NanoDrop Technologies, Wilmington, DE, USA) was used to quantify 125 extracted DNA. Amplification of the V5-V7 hyper variable region of the 16S rRNA bacterial

126

127

128

129

130

131

132

133

134

135

136

137

138

139

140

141

142

143

144

145

146

147

148

149

150

151

152

153

154

155

156

157 gene was conducted using primers 799F (5'-AACMGGATTAGATACCCKG-3') and 1193R (5'ACGTCATCCCCACCTTCC- $\left.3^{\prime}\right)$. The PCR reactions were conducted using the following program: 3 min of denaturation at $95^{\circ} \mathrm{C}, 27$ cycles of $30 \mathrm{~s}$ at $95^{\circ} \mathrm{C}, 30 \mathrm{~s}$ for annealing at $55^{\circ} \mathrm{C}$, and $45 \mathrm{~s}$ for elongation at $72{ }^{\circ} \mathrm{C}$, and a final extension at $72{ }^{\circ} \mathrm{C}$ for $10 \mathrm{~min}$. PCR reactions were performed in triplicate $20 \mu \mathrm{L}$ mixture containing $4 \mu \mathrm{L}$ of $5 \times$ FastPfu Buffer, $2 \mu \mathrm{L}$ of $2.5 \mathrm{mM}$ dNTPs, $0.8 \mu \mathrm{L}$ of each primer $(5 \mu \mathrm{M}), 0.4 \mu \mathrm{L}$ of FastPfu Polymerase and 10 ng of template DNA. The resulted PCR products were extracted from a $\%$ agarose gel and further purified using the AxyPrep DNA Gel Extraction Kit (Axygen Biosciences, Union City, CA, USA) and quantified using QuantiFluor ${ }^{\mathrm{TM}}$-ST (Promega, USA) according to the manufacturer's protocol. We conducted sequencing at Shanghai Majorbio Bio-pharm Technology (Shanghai, China), applying the MiSeq platform (Illumina, Inc., USA).

\section{Processing of sequencing data}

We selected QIIME software (Caporaso et al., 2010) to integrate the original sequencing data of the FASTQ format. The chimeric sequences were examined and eliminated using Usearch (vsesion $7.0 \mathrm{http} / / / \mathrm{drive} 5 . \mathrm{com} / \mathrm{usearch} /$ ). The $97 \%$ sequence similarity was identified as the OTU partition threshold for the classification results and was used to calculate bacterial community diversity and relative abundance. After that, in order to obtain the classification information of the species corresponding to each OTU, each OTU sequence ( $97 \%$ sequence similarity) was classified and analyzed using the RDP classifier (http://rdp.cme). And the reliability threshold using the silva132/16s_bacteria database is $70 \%$. The bacterial sequences were banked in the National Center for Biotechnology Information (NCBI) database under the Sequence Read Archive (SRA) accession: PRJNA611544.

\section{Statistical analysis}

Differences in the chemical properties among soil and litter and enzyme activities of each subdam were tested using the non-parametric test in SPSS Statistics version 24.0. Analysis of microbial community structure was performed using SPSS Statistics version 24.0 and SigmaPlot version 14.0. Pearson's correlation coefficient was employed to analyze the relationship among the environmental factors and microbial community diversity correlation analysis, and Venn diagram were performed using R3.5.3. Non-metric multidimensional scaling (NMDS) analysis was conducted on the bacterial community structure based on Bray-Curtis Dissimilarity, and ANOSIM was used to analyze inter-group differences. Additionally, variance inflation factor (VIF) analysis was used to eliminate the high collinearity of environmental factors using the 
158 "vegan package" in R 3.5.3. Following this, redundancy analysis (RDA) was carried out in 159 Canoco 5.0 (Microcomputer Power, USA). Finally, We used the interactive platform Gephi to 160 explore and visualize networks, and PICRUSt was used to predict bacterial community functions 161 based on the KEGG database.

\section{Results}

163 Sample properties and enzyme activities in Imperata cylindrica litter and soil

164

165

166

167

168

169

170

171

172

173

174

175

176

177

178

179

180

181

182

183

184

185

186

187

188

189

190

191

192

193

194

195

196

197

Soil nutrient content (TC_Soil and TN_Soil) steadily increased as phytoremediation progressed in the copper tailings dam (Table 1). The trend in SWC variation was consistent with TC_Soil and TN_Soil. C/N_Soil was highest in the S536 sub-dam. Significant differences in pH were observed between S516 and S560 sub-dams $(P<0.05)$. The heavy metals $\mathrm{As}$ and $\mathrm{Cd}$ accumulated in S536. For litter, TN_Litter and TC_Litter increased as phytoremediation progressed. The highest C/N_Litter value was observed in the S536 sub-dam (Table 1).

We found significant differences in cellulose, catalase and polyphenol oxidase in the litter of the three sub-dams $(P<0.05)$. Cellulase and catalase activities increased significantly as phytoremediation progressed. The highest polyphenol oxidase value was observed in the S536 sub-dam, while the lowest was observed in the S516 sub-dam. Additionally, no significant differences were found in urease and sucrase in litter among the three sub-dams (Table 2).

\section{Litter bacterial community composition and diversity}

The litter bacterial community structure differed over phytoremediation stages. Operational taxonomic unit (OTU) numbers of the bacterial community were highest in the S516 sub-dam (i.e., 298 OTUs), followed by the S536 (i.e., 198 OTUs) and the S560 (i.e., 163 OTUs) subdams. A total of 162 OTUs were shared in the bacterial community litter of the S516 and S536 sub-dams. Additionally, the three sub-dams shared 119 common OTUs. Proteobacteria, Actinobacteria and Bacteroidetes were the dominant bacterial phyla in the three sub-dams (Fig. 1). Proteobacteria had the highest relative abundance of the three sub-dams, while the relative abundance of the S560 sub-dam was significantly higher compared to the other three sub-dams $(P<0.05)$. The dominant bacteria in the three sub-dams were the classes Actinobacteria, Gammaproteobacteria and Alphaproteobacteria. The relative abundance of Gammaproteobacteria was the highest in the S560 sub-dam, and the relative abundance of Deltaproteobacteria gradually decreased with an increase in phytoremediation (Fig. 1A). Moreover, Burkholderiaceae and Sphingomonadaceae were the dominant bacterial families in the three sub-dams. Burkholderiaceae was the dominant bacteria in the S560 sub-dam, while Geodermatophilaceae abundance was highest in the S536 sub-dam (Fig. 1B).

Estimations using the Ace and Chaol indexes showed bacterial communities gradually increased as phytoremediation progressed, being highest in the S516 sub-dam. Variation trends from the Shannon index were consistent with the richness indexes (i.e., Ace and Chao1), revealing that there were significant differences among the three sub-dams $(P<0.05)$. However, the Simpson index gradually decreased as phytoremediation progressed (Fig. 2). NMDS analysis was performed on litter bacterial communities as shown in Fig. 3. Given that the stress value was 0.018 in this study, NMDS analysis results were considered well representative. Samples 
198

199

200

201

202

203

204

205

206

207

208

209

210

211

212

213

214

215

216

217

218

219

220

221

222

223

224

225

226

227

228

229

230

231

232

233

234

235

236

237

typically clustered together as phytoremediation progressed, while ANOSIM showed significant differences in bacterial community structure among the three sub-dams $(P=0.001)$.

\section{Ecological factor effects on bacterial community litter}

Correlation analysis showed a significant relationship between bacterial community litter diversity and TC_Soil, TN_Soil and pH (Fig. 4A). TC_Soil was significantly positively correlated to the Shannon-wiener index and bacterial richness indexes, but $\mathrm{pH}$ was negatively correlated to bacterial diversity. However, only TC_Litter was positively correlated to bacterial community diversity (Fig. 4B). Catalase was significantly positively correlated to all diversity indexes, while cellulase activity was positively correlated to the Shannon index (Fig. 4C). Zn was positively correlated to the litter community diversity and richness indexes (Fig. 4D).

Although soil and litter factors affected bacterial community structure, the main influencing factors varied in the different sub-dams (Fig. 5). We used VIF analysis to screen and remove high collinearity of physicochemical factors. RDA analysis showed that $43.22 \%$ of bacterial community variation was explained by physicochemical properties in soil. Moreover, axis 1 of the RDA plot explained nearly $26.24 \%$, and axis 2 explained a further $16.98 \%$. The bacterial community structure was mainly influenced by TN_Soil and SWC in the S516 sub-dam (Fig. 5A). This study also evaluated litter trait effects on bacterial community structure (Fig. 5B). Results showed that $70.5 \%$ of bacterial community variation in litter could be explained by litter traits. Both TC_Litter and TN_Litter had a significant effect on bacterial community structure (Fig. 5B). For enzyme activities, $76.65 \%$ of variation could be explained by extracellular enzyme activities (Fig. 5C). Axis 1 explained nearly 58.74\%, and axis 2 explained a further $17.91 \%$ (Fig. 5C). Urease, cellulase and polyphenol oxidase activities all had a significant effect on bacterial community structure (Fig. 5C). Additionally, dominant bacteria families, such as Sphingomonadaceae, Geodermatophilaceae and Beijerinckiaceae, were positively correlated to enzyme activities in the S516 and S536 sub-dams (Fig. 5C). Furthermore, $\mathrm{Zn}$ and $\mathrm{Cd}$ respectively had a significant effect on bacterial community structure in S516 and S536. The abundances of most bacteria classes were positively correlated with the contents of $\mathrm{Zn}$ and $\mathrm{Cd}$ while negatively corrected with $\mathrm{Cu}$ and $\mathrm{Pb}$.(Fig. 5D).This indicated that they could potentially play important roles in litter decomposition.

\section{Functional characteristics of litter bacterial communities}

This study identified some keystone families by building a co-occurrence network from litter bacterial communities (Fig.6). Keystone microbes can be generally defined as those species that have a disproportionate influence on ecosystems regardless of abundance, and they are crucial in the maintenance of the stability and the function of ecosystems as well as the resistance of system disturbances. Fimbriimonadaceae was the key bacterial family in litter bacteria, and the genus Pseudokineococcus played critical roles in the bacterial community (Fig.6). We also used PICRUSt to infer the functional genes of bacteria associated with litter decomposition, which is based on the KEGG database. The relative abundance of genes encoded with cellulase, hemicellulase and ligninolytic enzymes notably differed among the three sub-dams $(P<0.05)$. The relative abundance of genes encoded with endo-1,4-beta-xylanase, catalase, peroxidase, 
238

239

240

241

242

243

244

245

246

247

248

249

250

251

252

253

254

255

256

257

258

259

260

261

262

263

264

265

266

267

268

269

270

271

272

273

274

275

276

277

endo-1,5-alpha-L-arabinosidase, alpha-glucuronidase and 1,4-beta-xylosidase were significantly higher in the S536 sub-dam compared to the S516 and S560 sub-dams. Gene encoded $\beta$ glucosidase increased as phytoremediation progressed. Additionally, only genes encoded with alpha-amylase ( $\alpha$-amylase) were found in amylolytic enzymes, and their relative abundance was lower (Fig. 7).

\section{Discussion}

\section{Imperata cylindrica litter and soil properties}

In the study area, soil nutrient content increased as phytoremediation progressed, which is consistent with a previous study (Jia et al., 2019). The ratio between total soil carbon and nitrogen content reflected both the soil quality and nutrient characteristics (Wang \& Yu, 2008), which is associated with the decomposition rate of soil organisms. Our study found higher soil $\mathrm{C} / \mathrm{N}$ during different phytoremediation stages, indicating that soil $\mathrm{TN}$ was one of main limiting factors in the copper tailings dam. Moreover, litter $\mathrm{C} / \mathrm{N}$ had an effect on litter decomposition. It has been reported that the higher the carbon is, the lower the decomposition rate will be (Bryant et al., 1998; Magill et al., 2000). In this study, the S536 sub-dam had the highest soil C/N, which could speculate that the decomposition rate of litter and soil organic carbon in this sub-dam was relatively slow compared to the other two sub-dams. Furthermore, litter decomposition is influenced by many factors. In this study, cellulase and catalase in I. cylindrica litter were lower during the early remediation stage when heavy metal content in soil was higher. Similarly, Xue et al. (2018) found that lead $(\mathrm{Pb})$ inhibited cellulase and laccase activities in Phyllostachys pubescens litter while also inhibiting the degradation of this species. In previous studies, lead and cadmium (Cd) content seriously exceeded the copper tailings dam standard (Jia et al., 2018); thus, heavy metal content in the soil of our study site could also influence litter properties.

\section{Bacterial community composition in Imperata cylindrica litter}

Bacterial community diversity in litter gradually increased as phytoremediation progressed, which is associated with an increase in nutrient content in soil and litter ( $\mathrm{Lu}$ et al., 2019). Proteobacteria and Actinobacteria were the dominant bacterial phyla in litter in all three subdams (i.e., S516, S536 and S560). Many studies found that Proteobacteria and Actinobacteria were the dominant bacterial phyla communities in different soil and litter types (Bonanomi et al. 2019; Zhang et al., 2019), indicating that the adaption ability of these two bacterial phyla communities to this type of environment degradation is strong, subsequently playing a vital role in litter decomposition. Moreover, Actinobacteria and Alphaproteobacteria were the dominant bacterial classes in litter in all three sub-dams, and played a critical role in carbon and nitrogen cycling (Juhnke et al., 1988), which is essential in the decomposition of litter and the growth of plants. The relative abundance of the class Gammaproteobacteria in this study was the highest in the S560 sub-dam, which was due to the poor available nutrition during the early stage of remediation. This class, however, was strongly adaptable in its ability to dissolve phosphates in soil (Brabcova et al., 2016). At a family level, Sphingomonadaceae can produce cellulase, while its facility in organic matter decomposition is wide ranging, even including some complex organic matter (Boberg et al., 2011). In our study, Sphingomonadaceae was the dominant

Peer] reviewing PDF | (2020:04:47489:1:2:NEW 20 Jun 2020) 
278 bacterial family in all three sub-dams, indicating that its members play a critical role in litter 279 decomposition in copper tailings dams.

280 Relationships between litter bacterial communities and environmental factors

281

282

283

284

285

286

287

288

289

290

291

292

293

294

295

296

297

298

299

300

301

302

303

304

305

306

307

308

309

310

311

312

313

314

315

316

317

Although litter properties have been widely shown to influence bacterial community structure (He et al., 2019; Yan et al., 2018), the driving factors that affect bacterial litter communities within different ecosystems remain inconsistent between studies (Wang et al., 2019). Soil and litter properties affect activities associated with extracellular enzymes and bacterial community characteristics (Petraglia et al., 2018; Yan et al., 2018). In our study, total litter carbon and nitrogen significantly affected bacterial community structure. Similarly, Xu et al. (2020) found that carbon, phosphorus and $\mathrm{pH}$ were the key factors that influenced bacterial community litter and soil composition of Robinia pseudoacacia on the Loess Plateau. Zhao et al. (2017) also found that total litter carbon was the main regulatory factor of bacterial community structure during litter decomposition processes. Moreover, Zeng et al. (2017) found that total carbon, nitrogen and phosphorus in litter were critical factors that influenced bacterial community composition. In this study, we combined bacterial community structure analysis with extracellular enzyme activity analysis to explore the influence of environmental factors on microbial community structure. We found that urease, cellulose and polyphenol oxidase in litter were closely correlated to the bacterial community. However, critical factors varied among the different phytoremediation stages. Additionally, the families Sphingomonadaceae, Geodermatophilaceae and Beijerinckiaceae were positively correlated to a variety of extracellular enzyme activities. This was because these bacterial families are able to produce a variety of enzymes that are used in organic matter degradation, thus playing an important role in litter decomposition processes.

Heavy metals, such as the $\mathrm{Cu}, \mathrm{Zn}, \mathrm{Fe}$ and $\mathrm{Mg}$, were essential for microbial growth and participate in many important biological metabolic processed at low concentrations (Chen et al. 2020; Zampieri et al., 2016). However, at high concentrations, they had significant effect on the growth, morphology and metabolism of microorganisms, leading to a decrease in microbial diversity (Chen et al., 2020; Zampieri et al., 2016). Many studies showed that the heavy metals significantly affect the microbial abundance, diversity, the abundance of the functional classes and gene families(Chen et al., 2018; Feng et al., 2018; Liu et al., 2018b). In this study, the abundances of most bacteria classes were positively correlated with the $\mathrm{Zn}$ and $\mathrm{Cd}$, indicating that these microorganisms had high tolerance to $\mathrm{Zn}$ and $\mathrm{Cd}$. The dominant bacterial classes were positively correlated with enzyme activities associated with litter degradation. This suggested that heavy metals might influence enzyme identities and activities by altering the microbial communities compositions, then affect the litter degradations.

\section{Functional characteristics of litter bacterial communities}

Using PICRUSt, genes encoded with cellulase, hemicellulase and LME were found in litter bacterial communities, demonstrating the critical potential of bacterial communities in litter decomposition. However, our results showed that the relative abundance of genes encoded with cellulase and hemicellulase were significantly higher in the S536 sub-dam compared to the other 
318 sub-dams $(P<0.05)$, which was inconsistent with our results on cellulase and sucrase activities. 319 Differences between the abundance of functional genes and enzymatic activities was due to the 320 role that other microorganisms play in litter decomposition, such as fungi. Studies found the 321 Basidiomycota produces a wide range of LMEs and cellulase, while also controlling litter 322 decomposition (Zhang et al., 2019). Furthermore, our study found that the dominate litter 323 bacterial community could encode $\alpha$-amylase at the early stage of phytoremediation (Bani et al., 324 2018). However, bacteria that encode hemicellulase and peroxidase gradually became the 325 dominant bacterial communities as phytoremediation progressed. This could be due to the low

326

327

328

329

330

331

332

333

334

335

336

337

338

339

340

341

342

343

344

345

346

347

348

349

350

351

352

353

354

355

356

357 nutrient content within the environment during the initial stage of phytoremediation, and the fact that bacteria can rapidly utilize substances in litter to meet their growth needs (Stirling et al., 2019). It should be noted that functional gene distribution can only predict the metabolic potential and ecological function of a bacterial community. In other words, functional gene distribution does not reflect the real metabolic activities and ecological functions of bacterial communities (Liang et al., 2019). Additionally, differences between functional gene abundance and gene expression have also been reported in some studies (Hollister et al., 2010; Ossola A, 2017). Therefore, bacterial functional characteristics in litter decomposition along with gene expression and associated regulations must be further investigated in future studies.

This study suggested that bacterial community also play a crucial role in the degradation of litters, and heavy metal influence the degradation of litters by altering the composition of the microbial community. However, one limitation of this work was that we don't cover the different stages of litter degradation. In the process of litter degradation, the chemistry of the organic substrate continuously changes, which led to various microbial community structures (Berj et al., 2008). In addition, the climate change was also one of the main factors affecting litter degradation (Liang et al., 2019). Future studies will take into account the changes in microbial community structure and function at different degradation of the I. cylindrica litter. Such studies will further strengthen our understanding of the relationship between the microbial community and litter decomposition in pollution area, and is critically important to understand the circulation of substances in copper tailings dams

\section{Conclusions}

This study found significant differences in physiochemical soil and litter properties within different sub-dams. Total carbon, cellulase and catalase in I. cylindrica litter increased as phytoremediation progressed. Actinobcteria, Gammaproteobacteria and Alphaproteobacteria were the dominate litter bacteria in the different sub-dams. Moreover, total litter carbon and nitrogen were the key influencing factors of bacterial community structure. The $\alpha$-diversity of the litter bacterial community increased as phytoremediation progressed, and the total carbon soil content and the total litter carbon content were positively correlated to bacterial $\alpha$-diversity. Finally, bacterial communities encoded with $\alpha$-amylase were the dominant microbial communities during the initial phytoremediation stage; however, bacterial communities encoded with hemicellulase and peroxidase gradually became the dominant microbial communities as phytoremediation progressed. 
358

359

360

361

362

363

364

365

366

367

368

369

370

371

372

373

374

375

376

377

378

379

380

381

382

383

384

385

386

387

388

389

390

391

392

393

394

395

396

397

\section{Acknowledgements}

This study was supported by the National Natural Science Foundation of China (Grant No. 31600308), the fund for Shanxi "1331 Project", China (Ecological restoration of damaged soil system), Shanxi Province Science Foundation for Excellent Young Scholars (Grant No. 201901D211196), Scientific and Technological Innovation Programs of Higher Education Institutions in Shanxi (Grant No.2019L0005), Shanxi Province Graduate Education Innovation Project (Grant No.2019SY029), Shanxi Province Foundation for Returnees (Grant No. 2016006), and the Higher Education Institution Project of Shanxi Province: Ecological Remediation of Soil Pollution Disciplines Group (Grant No. 20181401).

\section{References}

Bani A, Pioli S, Ventura M, Panzacchi P, Borruso L, Tognetti R, Tonon G, Brusetti L. 2018. The role of microbial community in the decomposition of leaf litter and deadwood. Applied Soil Ecology 126: 75-84 DOI 10.1016/j.apsoil.2018.02.017.

Berg B. 2014. Decomposition patterns for foliar litter - A theory for influencing factors. Soil Biology and Biochemistry 78: 222-232 DOI 10.1016/j.soilbio.2014.08.005.

Berg B, Mcclaugherty C. 2008. Plant Litter. Decomposition, Humus Formation, Carbon Sequestration. Springer Berlin Heidelberg DOI: 10.1007/978-3-642-38821-7.

Boberg JB, Ihrmark K, Lindahl BD. 2011. Decomposing capacity of fungi commonly detected in Pinus sylvestris needle litter. Fungal Ecology 4: 110-114 DOI 10.1016/j.funeco.2010.09.002.

Boer WD, Folman LB, Summerbell RC, Boddy L. 2005. Living in a fungal world: impact of fungi on soil bacterial niche development. FEMS Microbiology Reviews 29: 795-811 DOI 10.1016/j.femsre.2004.11.005.

Bonanomi G, Filippis FD, Cesarano G, Storia AL, Incerti G. 2019. Linking bacterial and eukaryotic microbiota to litter chemistry: Combining next generation sequencing with C13 CPMAS NMR spectroscopy. Soil Biology and Biochemistry 129:110-121 DOI 10.1016/j.soilbio.2018.11.013.

Brabcova V, Novakova M, Davidova A, Baldrian P. 2016. Dead fungal mycelium in forest soil represents a decomposition hotspot and a habitat for a specific microbial community. New Phytologist 210:1369-1381 DOI 10.1111/nph.13849.

Bryant DM, Holland EA, Seastedt TR, Walker MD. 1998. Analysis of litter decomposition in an alpine tundra. Canadian Journal of Botany-Revue Canadienne de Botanique 76:12951304 DOI 10.1139/b98-117.

Caporaso JG., Kuczynski J, Stombaugh J, Bittinger K, Bushman FD, Costello EK, Fierer N, Pena AG, Goodrich JK, Gordon JI. 2010. QIIME allows analysis of high-throughput community sequencing data. Nature Methods 7:335-336 DOI 10.1038/nmeth.f.303.

Chen Y, Jiang Y, Huang H, Mou L, Ru J, Zhao J, Xiao S. 2018. Long-term and highconcentration heavy-metal contamination strongly influences the microbiome and functional genes in Yellow River sediments. Science of the Total Environment 637638:1400-1412 DOI 10.1016/j.scitotenv.2018.05.109. 
398

399

400

401

402

403

404

405

406

407

408

409

410

411

412

413

414

415

416

417

418

419

420

421

422

423

424

425

426

427

428

429

430

431

432

433

434

435

436

437

Chen Z, Wang Q, Ma J, Zou, Yu Q, Jiang L. 2020. Fungal community composition change and heavy metal accumulation in response to the long-term application of anaerobically digested slurry in a paddy soil. Ecotoxicology and Environmental Safety 196:110453 DOI 10.1016/j.ecoenv.2020.110453.

Cotrufo MF, Soong JL, Horton AJ, Campbell EE, Haddix M, Wall D H, Parton WJ. 2015. Formation of soil organic matter via biochemical and physical pathways of litter mass loss. Nature Geoscience 8:776 DOI 10.1038/ngeo2520.

Fang X, Qing Y, Li X, Wang L, Wang T, Zhu M, Qu Y. 2010. Progress on cellulase and enzymatic hydrolysis of lignocellulosic biomass. Chinese Journal of Biotechnology 26:864-869.

Feng G, Xie T, Wang X, Bai J, Tang L, Zhao H, Wei W, Wang M, Zhao Y. 2018. Metagenomic analysis of microbial community and function involved in Cd-contaminated soil. BMC Microbiology 18:1-13 DOI 10.1186/s12866-018-1152-5.

Fissore C, Jurgensen MF, Pickens J, Miller C, Page-Dumroese D, Giardina CP. 2016. Role of soil texture, clay mineralogy, location, and temperature in coarse wood decomposition-a mesocosm experiment. Ecosphere 7 DOI 10.1002/ecs2.1605.

Guan S. 1986. Soil enzyme and its research method. Agriculture press.

Guo Z, Wang H. 2013. Soil heavy metal pollution in nonferrous metal mining areas and its remediation. Economic Research Guide 286-287.

He M, Zhao R, Tian Q, Huang L, Liu F. 2019. Predominant effects of litter chemistry on lignin degradation in the early stage of leaf litter decomposition. Plant and Soil DOI 10.1007/s11104-019-04207-6.

Hollister EB, Schadt CW, Palumbo AV, James Ansley R, Boutton TW. 2010. Structural and functional diversity of soil bacterial and fungal communities following woody plant encroachment in the southern Great Plains. Soil Biology and Biochemistry 42:1816-1824 DOI 10.1016/j.soilbio.2010.06.022.

Jia T, Cao M, Jing J, Liu J, Chai B. 2017. Endophytic fungi and soil microbial community characteristics over different years of phytoremediation in a copper tailings dam of Shanxi, China. Science of The Total Environment 574:881-888 DOI 10.1016/j.scitotenv.2016.09.161.

Jia T, Guo T, Cao M, Chai B. 2018. Effects of heavy metals on phyllosphere and rhizosphere microbial community of Bothriochloa ischaemum. Applied Sciences 8:1419 DOI 10.3390/app8091419.

Jia T, Wang R, Chai B. 2019. Effects of heavy metal pollution on soil physicochemical properties and microbial diversity over different reclamation years in a copper tailings dam. Journal of Soil and Water Conservation 74:439-448 DOI 10.2489/jswc.74.5.439.

Jia T, Wang R, Fan X, Chai B. 2018. A comparative study of fungal community structure, diversity and richness between the soil and the phyllosphere of native grass species in a copper tailings dam in Shanxi province, China. Applied Sciences 8:1297 DOI 10.3390/app8081297.

Peer) reviewing PDF | (2020:04:47489:1:2:NEW 20 Jun 2020) 
438

439

440

441

442

443

444

445

446

447

448

449

450

451

452

453

454

455

456

457

458

459

460

461

462

463

464

465

466

467

468

469

470

471

472

473

474

475

Johnsen AR, Jacobsen OS. 2008. A quick and sensitive method for the quantification of peroxidase activity of organic surface soil from forests. Soil Biology and Biochemistry 40:814-821 DOI 10.1016/j.soilbio.2007.10.017.

Juhnke ME, Mathre DE, Sands DC. 1988. Identification and characterization of rhizospherecompetent bacteria of wheat. Applied and Environmental Microbiology 53:2793-2799 DOI 10.1002/bit.260300813.

Keiluweit M, Nico P, Harmon ME, Mao J, Pett-Ridge J, Kleber M. 2015. Long-term litter decomposition controlled by manganese redox cycling. Proceedings of the National Academy of Sciences of the United States of America 112:E5253-E5260 DOI 10.1073/pnas.1508945112.

Liang T, Yang G, Ma Y, Yao Q, Li G. 2019. Seasonal dynamics of microbial diversity in the rhizosphere of Ulmus pumila L. var. sabulosa in a steppe desert area of Northern China. PeerJ 7:e7526 DOI 10.7717/peerj.7526.

Liu J, Li C, Jing J, Zhao P, Luo Z, Cao M, Ma Z, Jia T, Chai B. 2018a. Ecological patterns and adaptability of bacterial communities in alkaline copper mine drainage. Water Research 133:99-109 DOI 10.1016/j.watres.2018.01.014.

Liu Y, Delgadobaquerizo M, Bi L, Zhu J, He J. 2018b. Consistent responses of soil microbial taxonomic and functional attributes to mercury pollution across China. Microbiome 6:1-12 DOI 10.1186/s40168-018-0572-7.

Lopez-Mondejar R, Zuehlke D, Becher D, Riedel K, Baldrian P. 2016. Cellulose and hemicellulose decomposition by forest soil bacteria proceeds by the action of structurally variable enzymatic systems. Scientific Reports 6 DOI 10.1038/srep25279.

Lu Y, Li K, Liang Q, Li C, Zhang C. 2019. Effects of leaf litter decomposition on bacterial community structure in the leaf litter of four dominant tree species in Mount Tai. Acta Ecologica Sinica 39:3175-3186.

Magill AH, Aber JD, Berntson GM, Mcdowell WH, Nadelhoffer KJ, Melillo JM, Steudler P. 2000. Long-term nitrogen additions and nitrogen saturation in two temperate forests. Ecosystems 3:238-253 DOI 10.1007/s100210000023.

Nakamura R, Kajino H, Kawai K, Nakai W, Okada N. 2019. Diverse recalcitrant substrates slow down decomposition of leaf litter from trees in a serpentine ecosystem. Plant and Soil DOI 10.1007/s11104-019-04183-x.

Ossola A ACHA. 2017. Contrasting effects of urban habitat complexity on metabolic functional diversity and composition of litter and soil bacterial communities. Urban Ecosystems 20:595-607 DOI 10.1007/s11252-016-0617-2.

Paz-Alberto AM, Sigua GC, Baui BG, Prudente JA. 2007. Phytoextraction of leadcontaminated soil using vetivergrass (Vetiveria Zizanioides L.), cogongrass (Imperata cylindrica L.) and carabaograss (Paspalum Conjugatum L.). Environmental Science and Pollution Research International, 14: 498-504 DOI: 10.1065/espr2007.05.415. 
476

477

478

479

480

481

482

483

484

485

486

487

488

489

490

491

492

493

494

495

496

497

498

499

500

501

502

503

504

505

506

507

508

509

510

511

512

513

514

Petraglia A, Cacciatori C, Chelli S, Fenu G, Carbognani M. 2018. Litter decomposition: effects of temperature driven by soil moisture and vegetation type. Plant and Soil 1-14 DOI 10.1007/s11104-018-3889-x.

Saiya-Cork KR, Sinsabaugh RL, Zak DR. 2002. The effects of long term nitrogen deposition on extracellular enzyme activity in an Acer saccharum forest soil. Soil Biology and Biochemistry 34:1309-1315 DOI 10.1016/s0038-0717(02)00074-3.

Santschi F, Gounand I, Harvey E, Altermatt F. 2018. Leaf litter diversity and structure of microbial decomposer communities modulate litter decomposition in aquatic systems. Functional Ecology 32 DOI 10.1111/1365-2435.12980.

Schimel J, Becerra CA, Blankinship J. 2017. Estimating decay dynamics for enzyme activities in soils from different ecosystems. Soil Biology and Biochemistry 114:5-11 DOI 10.1016/j. soilbio.2017.06.023.

Stirling E, Macdonald LM, Smernik RJ, Cavagnaro TR. 2019. Post fire litters are richer in water soluble carbon and lead to increased microbial activity. Applied Soil Ecology 136:101-105 DOI 10.1016/j.apsoil.2018.12.021.

Tan X, Machmuller MB, Cotrufo MF, Shen W. 2020. Shifts in fungal biomass and activities of hydrolase and oxidative enzymes explain different responses of litter decomposition to nitrogen addition. Biology and Fertility of Soils 4 DOI 10.1007/s00374-020-01434-3.

Wang H, Mo J, Xue J, Fang Y, Li J. 2006. Effects of elevated nitrogen deposition on the activities of enzymes in forest litter decomposition: a review. Journal of Tropical and Subtropical Botany 14(6):539-546 DOI 10.3969/j.issn.1005-3395.2006.06.016.

Wang J, Liu L, Wang X, Yang S, Zhang B, Li P, Qiao C, Deng M, Liu W. 2017. High nighttime humidity and dissolved organic carbon content support rapid decomposition of standing litter in a semi-arid landscape. Functional Ecology 31 DOI 10.1111/13652435.12854.

Wang S, Yu G. 2008. Ecological stoichiometry characteristics of ecosystem carbon, nitrogen and phosphorus elements. Acta Ecologica Sinica 3937-3947 DOI 10.3321/j.issn:10000933.2008.08.054.

Wang W, Chen D, Sun X, Zhang Q, Zhang S. 2019. Impacts of mixed litter on the structure and functional pathway of microbial community in litter decomposition. Applied Soil Ecology 144:72-82 DOI 10.1016/j.apsoil.2019.07.006.

Wang W, Zhang Q, Sun X, Chen D, Insam H. Koide RT, Zhang S. 2020. Effects of mixedspecies litter on bacterial and fungal lignocellulose degradation functions during litter decomposition. Soil Biology and Biochemistry 141:107690 DOI 10.1016/j.soilbio.2019.107690.

Xu M, Lu X, Xu Y, Zhong Z, Zhang W, Ren C, Han X, Yang G, Feng Y. 2020. Dynamics of bacterial community in litter and soil along a chronosequence of Robinia pseudoacacia plantations. Science of the Total Environment 703: 135613 DOI 10.1016/j.scitotenv.2019.135613. 
515 Yan J, Lei W, Yu H, Tsang YF, Ying S. 2018. Plant litter composition selects different soil 516 microbial structures and in turn drives different litter decomposition pattern and soil carbon 517 sequestration capability. Geoderma 319:194-203 DOI 10.1016/j.geoderma.2018.01.009.

518 Yu C, Harrold DR, Claypool JT, Simmons BA, Singer SW, Simmons CW, VanderGheynst

519 JS. 2017. Nitrogen amendment of green waste impacts microbial community, enzyme

520 secretion and potential for lignocellulose decomposition. Process Biochemistry 52:214-222

521 DOI 10.1016/j.procbio.2016.11.002.

522

Zampieri B, Pinto A, Schultz L, Oliveira M, Oliveira AJ. 2016. Diversity and distribution of 523

524

525

526

527

528

529 heavy metal-resistant bacteria in polluted sediments of the Araça Bay, São Sebastião (SP), and the relationship between heavy metals and organic matter concentrations. Microbial Ecology 72:582-594 DOI 10.1007/s00248-016-0821-x.

Zhang W, Yang K, Lyu Z, Zhu J. 2019. Microbial groups and their functions control the decomposition of coniferous litter: A comparison with broadleaved tree litters. Soil Biology and Biochemistry 133:196-207 DOI 10.1016/j.soilbio.2019.03.009.

530

Zhao B, Xing P, Wu QL. 2017. Microbes participated in macrophyte leaf litters decomposition in freshwater habitat. FEMS Microbiology Ecology 93 DOI 10.1093/femsec/fix108. 
Figure 1

The relative abundances of litter bacterial community at the levels of class (A) and family (B) with different years of phytoremediation. 

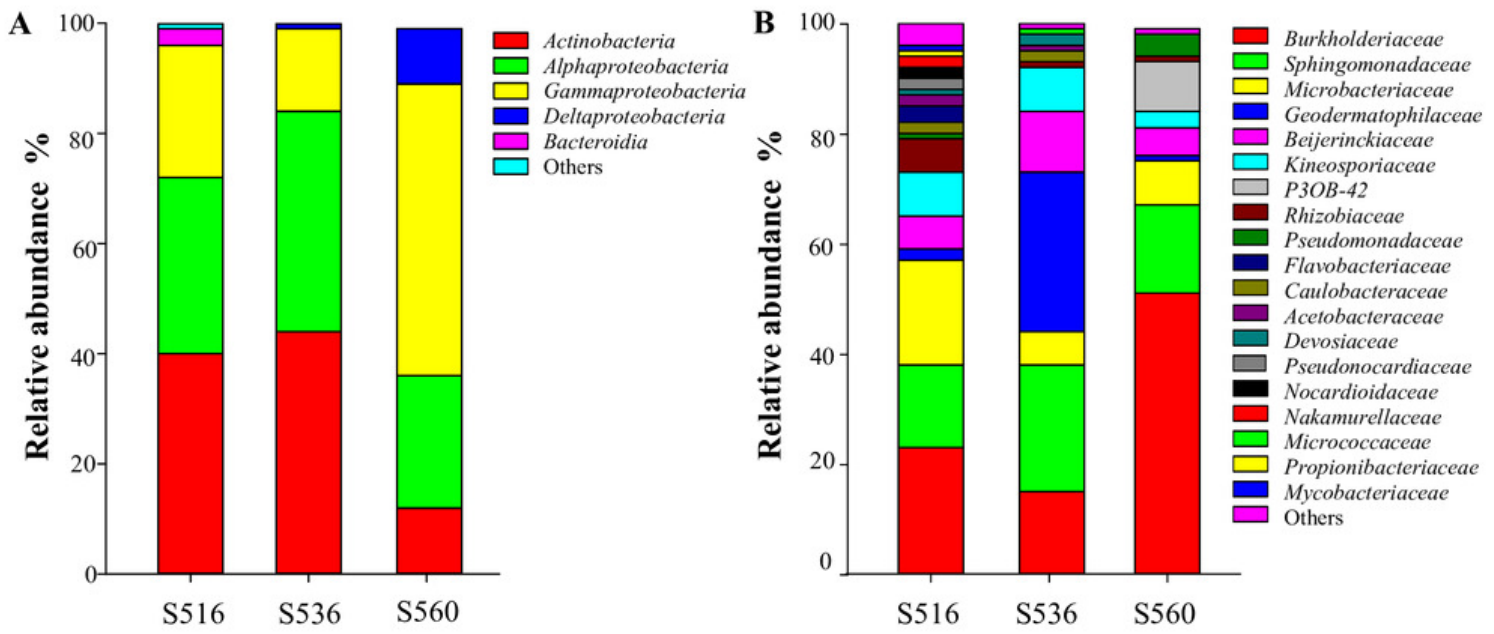
Figure 2

Diversity indices of litter bacterial community with different years of phytoremediation.

The bacterial diversity indices included Shannon-wiener (A), Simpson (B) Ace index (C) and Chaol (D). Different lowercase letters indicate significant differences, $P<0.05$.
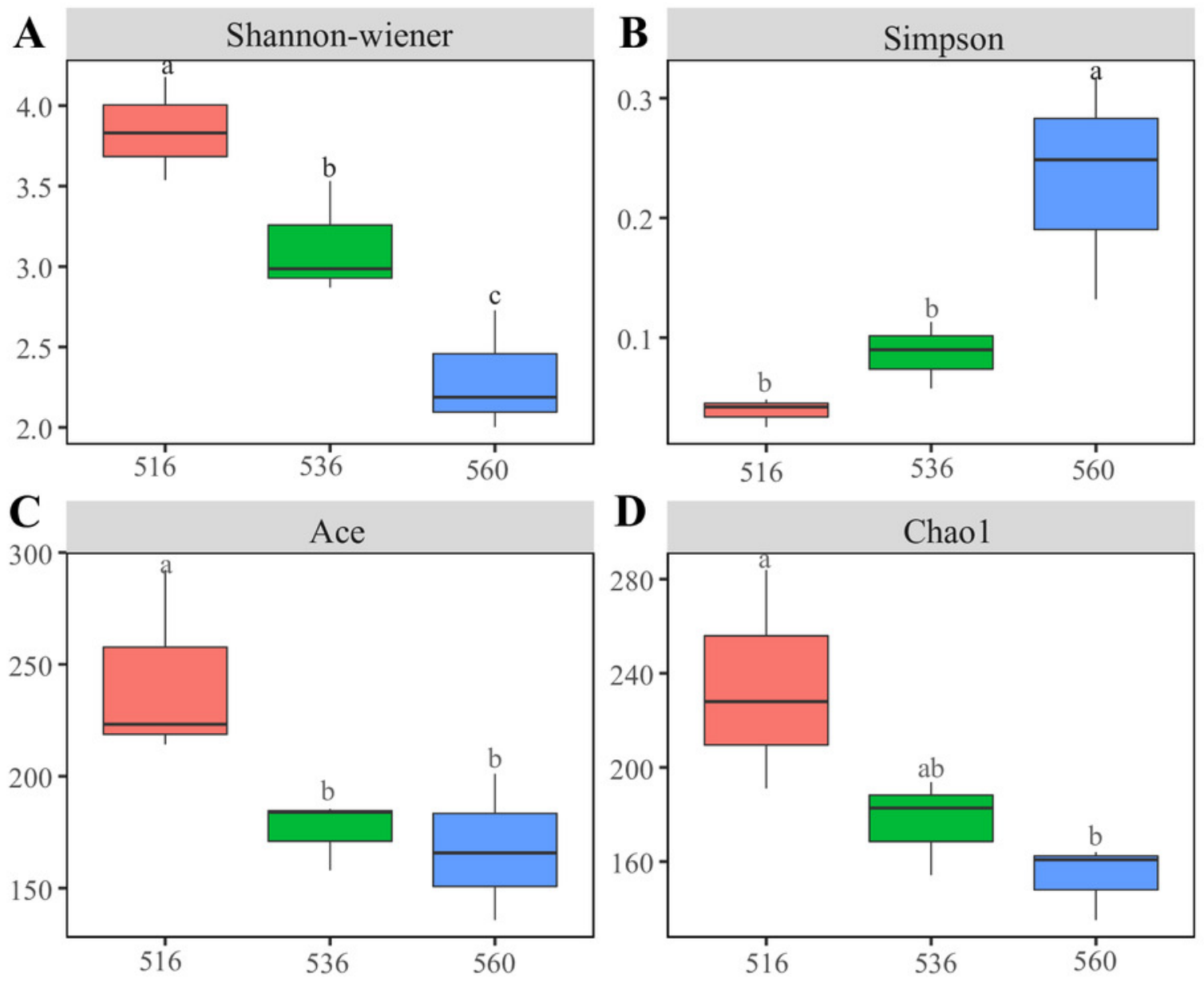

560 
Figure 3

Non-metric multidimensional scaling (NMDS) of litter samples at different years of phytoremediation based on the relative abundance of bacterial OTU.

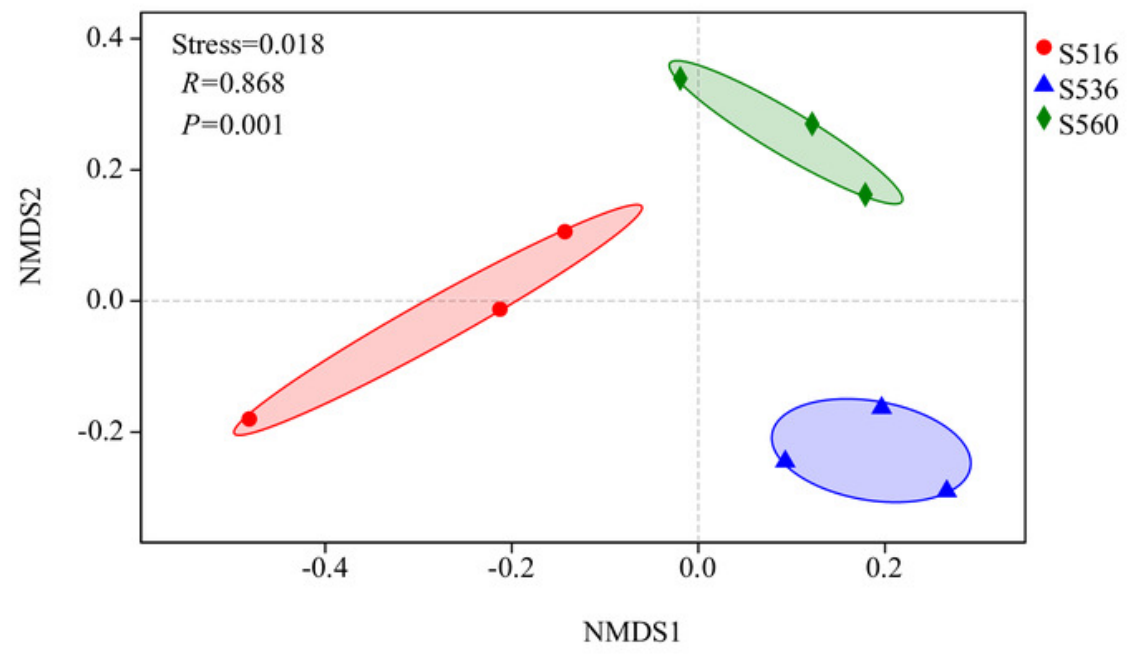




\section{Figure 4}

The Pearson correlation between the environmental factors and litter bacterial diversitie.

The environmental factors included soil properties (A), litter properties (B), enzyme activities of litter (C) and heavy metals (D). The soil properties included total carbon (TC_Soil), total nitrogen (TN_Soil ), ration of carbon and nitrogen (C/N_Soil), pH and soil water content (SWC). The litter properties included total carbon (TC_Litter), total nitrogen (TN_Litter) and ration of carbon and nitrogen (C/N_Litter) and the enzyme activities of litters included cellulase, urease, sucrase, catalase and polyphenol oxidase. * Correlation is significant at the 0.05 level (2-tailed), ${ }^{* *}$ Correlation is significant at the 0.01 level (2-tailed). 

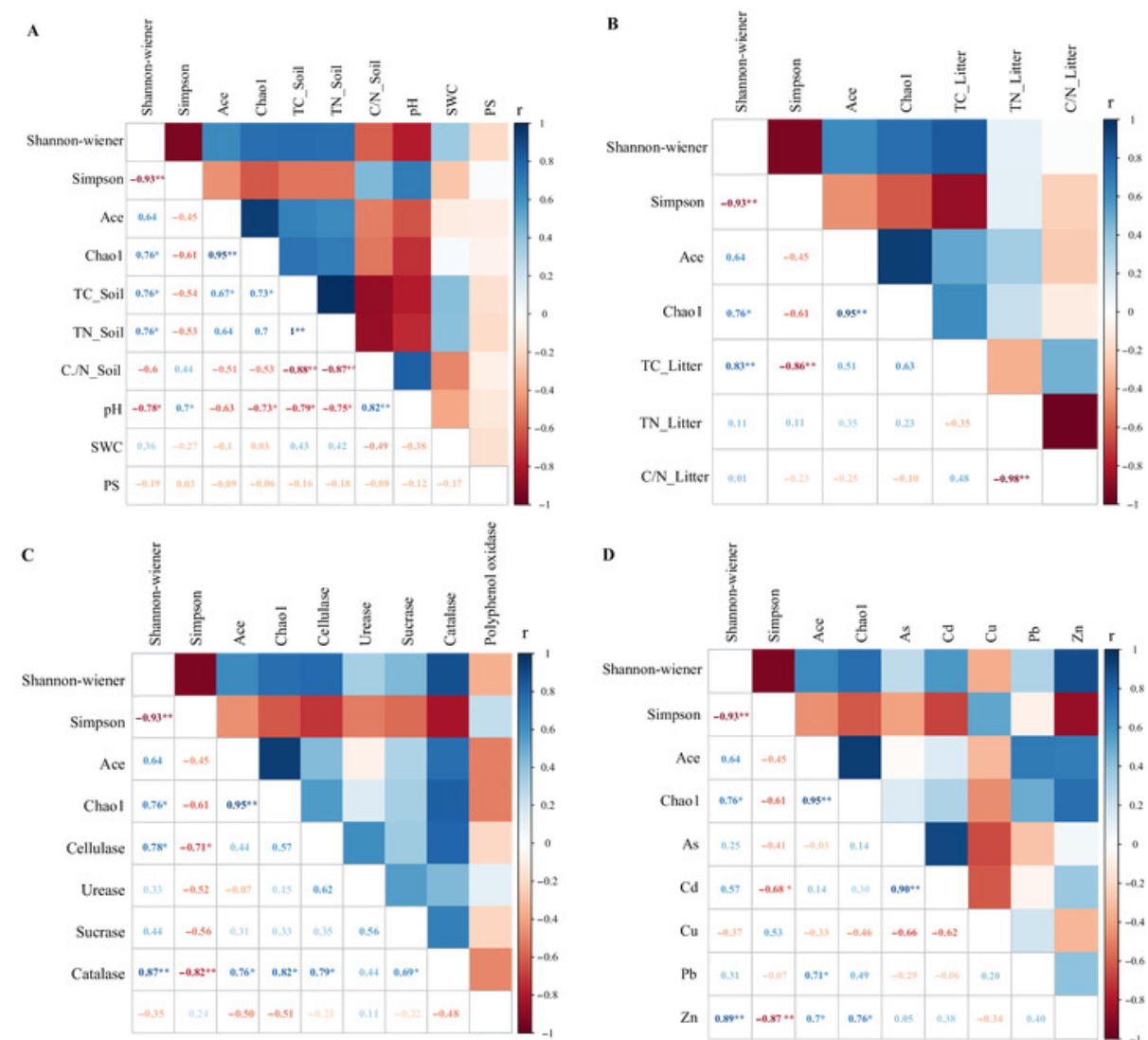
Figure 5

RDA analysis of bacterial community and environmental factors.

The environmental factors included soil properties (A), litter properties (B), enzyme activities of litter (C) and heavy metals (D), which were represented by red arrows. The black arrows represent the bacterial which were in the top five at the family level.
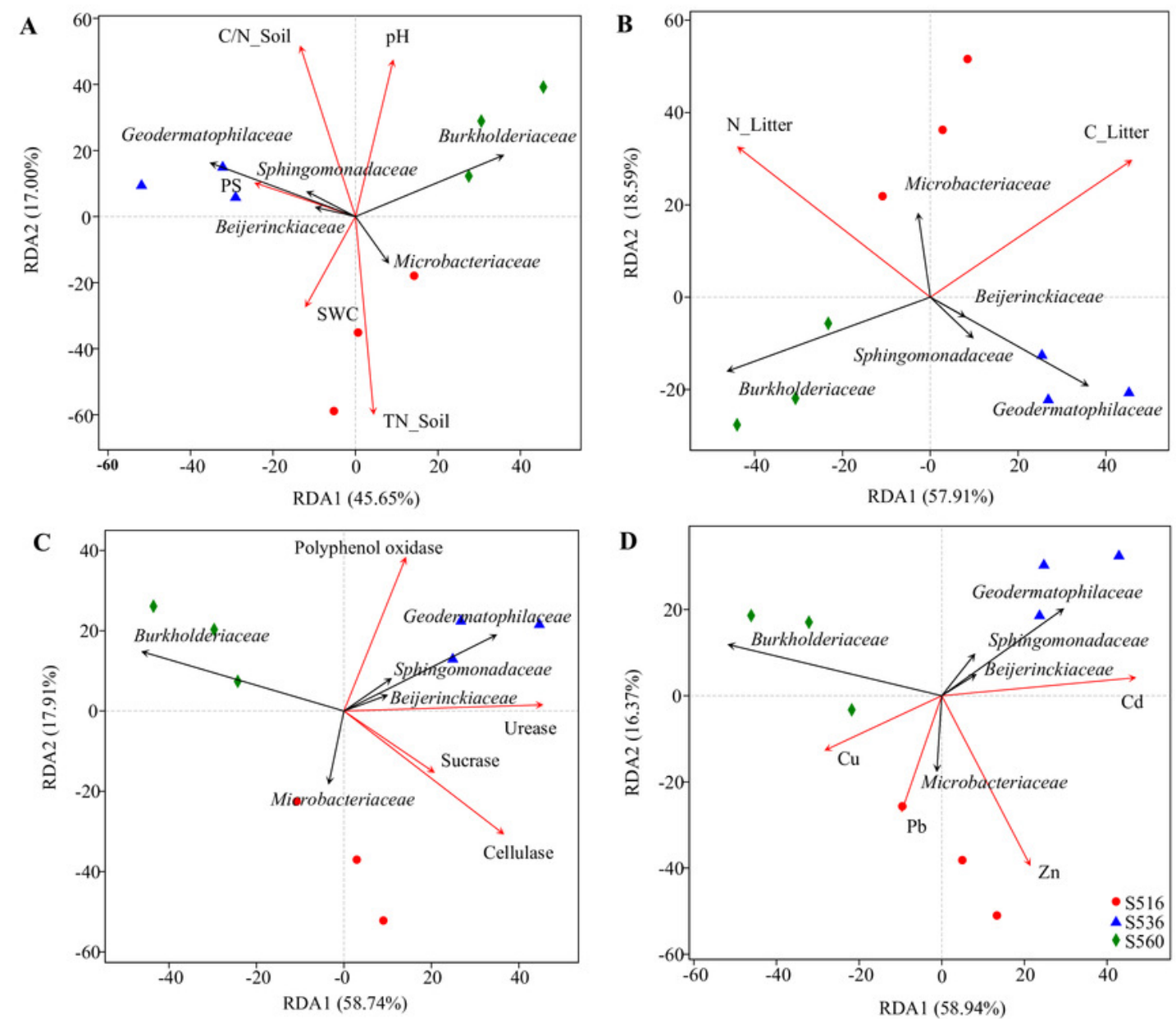
Figure 6

Co-occurrence network of bacterial taxa on litters.

Nodes represent bacteria families (A) and genus (B), whereas pink edges respectively represent positive connections between pairs of species. The symbol sizes are proportional to the $\mathrm{BC}$ of nodes and node color represent the taxonomy of different microbial groups.
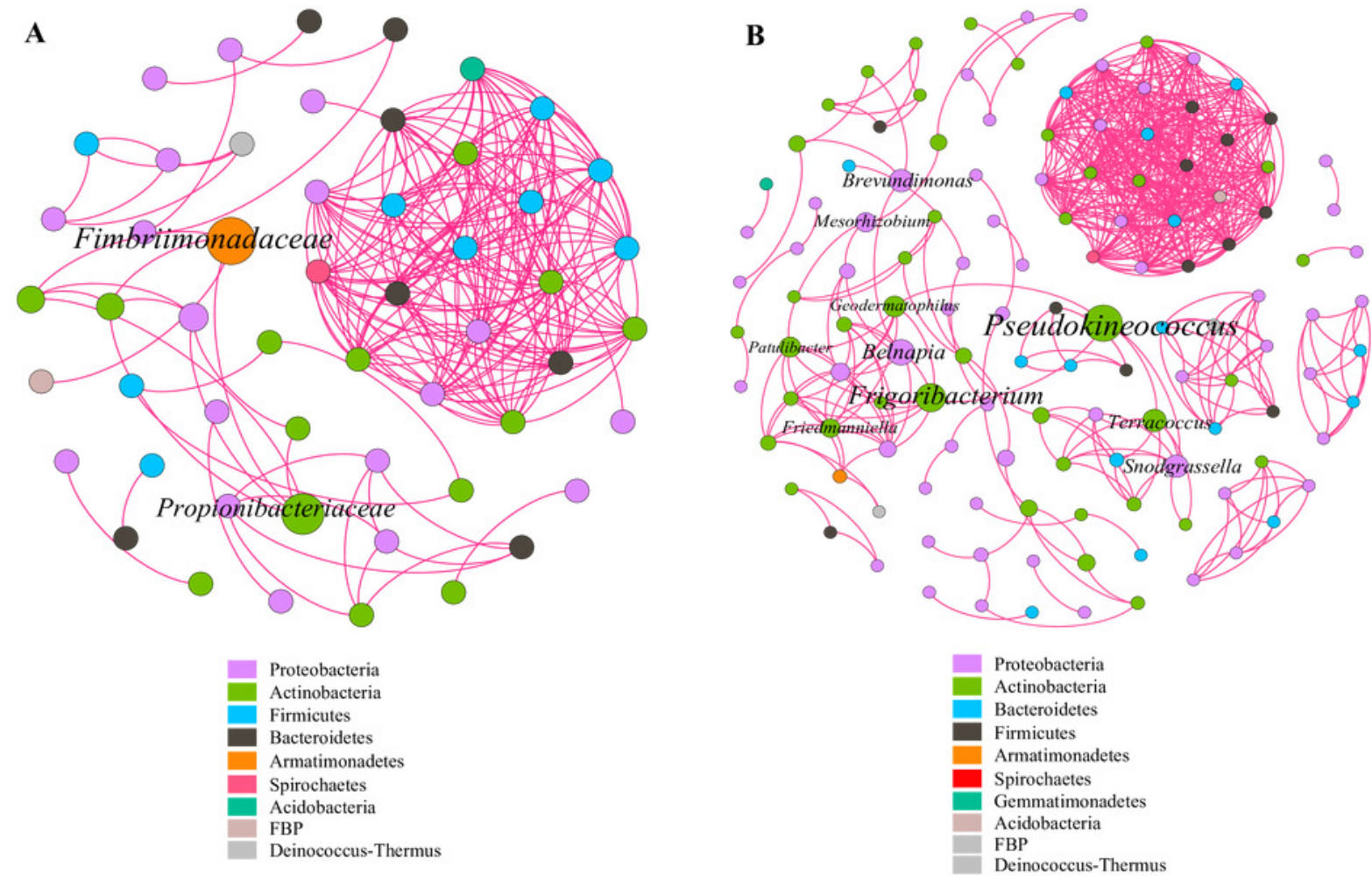


\section{Figure 7}

The relative abundance of functional genes related to litter degradation in litter bacterial community with different years of phytoremediation. The predicted functional analysis of the bacterial associated with litter degradation by PICRUSt.

The alpha-amylase was related to the decomposition of starch and other active substances. The endo-1,4-beta-xylanase, arabinan endo-1,5-alpha-L-arabinosidase, alpha-glucuronidase and xylan 1,4-beta-xylosidase were the enzymes related to hemicellulose decomposition. Endoglucanase and beta-glucosidase were involved in cellulose decomposition, and catalase/peroxidas were the main ligninase. Different letters indicated significant differences with years of phytoremediation, $P<0.05$. 


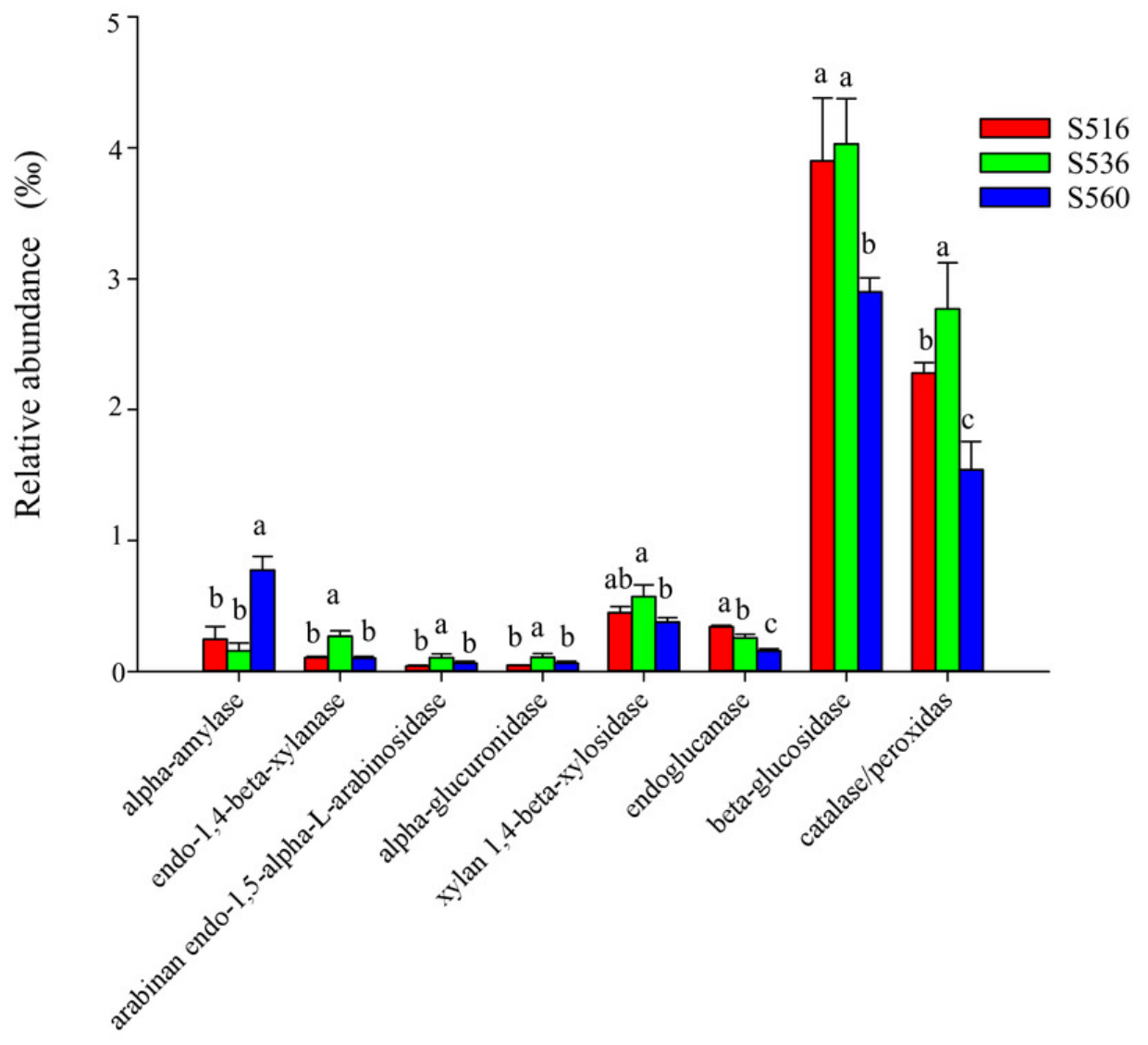




\section{Table $\mathbf{1}$ (on next page)}

The properties of soil and litters as phytoremediation processed.

Abbreviations mean total nitrogen (TN), total carbon (TC), the ratio of carbon and nitrogen $(\mathrm{C} / \mathrm{N})$, soil water content (SWC) and average particle size (PS). Data are means \pm standard deviation. Significant differences between sites $(P<0.05)$ are denoted with letters (Soil and heavy metals: $a>b$; Litter: $A>B$ ) 


\begin{tabular}{|c|c|c|c|c|}
\hline \multicolumn{2}{|c|}{ Physical and chemical factors } & \multirow{2}{*}{$\frac{\mathrm{S} 516}{2.143 \pm 0.788 \mathrm{a}}$} & \multirow{2}{*}{$\frac{\mathrm{S} 536}{0.647 \pm 0.193 \mathrm{~b}}$} & \multirow{2}{*}{$\begin{array}{r}\mathrm{S} 560 \\
0.557 \pm 0.207 \mathrm{~b}\end{array}$} \\
\hline Soil & TC_Soil (\%) & & & \\
\hline & TN_Soil (\%) & $0.143 \pm 0.0727 \mathrm{a}$ & $0.024 \pm 0.014 b$ & $0.022 \pm 0.013 \mathrm{~b}$ \\
\hline & C/N_Soil & $16.346 \pm 4.148 b$ & $30.198 \pm 6.656 a$ & $28.382 \pm 6.661 \mathrm{a}$ \\
\hline & SWC (\%) & $13.055 \pm 7.513 \mathrm{a}$ & $6.770 \pm 2.630 \mathrm{ab}$ & $5.547 \pm 3.138 b$ \\
\hline & $\mathrm{pH}$ & $7.944 \pm 0.252 b$ & $8.114 \pm 0.103 \mathrm{ab}$ & $8.218 \pm 0.161 \mathrm{a}$ \\
\hline & $\mathrm{PS}(\mu \mathrm{m})$ & $38.367 \pm 6.030 \mathrm{a}$ & $41.300 \pm 10.916 \mathrm{a}$ & $36.067 \pm 7.170 \mathrm{a}$ \\
\hline \multirow[t]{5}{*}{ Heavy metals } & As $\left(\mathrm{mg} \cdot \mathrm{kg}^{-1}\right)$ & $11.937 \pm 5.475 \mathrm{ab}$ & $25.441 \pm 9.495 \mathrm{a}$ & $4.577 \pm 1.299 \mathrm{~b}$ \\
\hline & $\mathrm{Cd}\left(\mathrm{mg} \cdot \mathrm{kg}^{-1}\right)$ & $5.967 \pm 0.659 b$ & $7.580 \pm 0.833 \mathrm{a}$ & $3.193 \pm 0.083 \mathrm{c}$ \\
\hline & $\mathrm{Cu}\left(\mathrm{mg} \cdot \mathrm{kg}^{-1}\right)$ & $418.408 \pm 123.080 \mathrm{a}$ & $347.032 \pm 18.937 \mathrm{a}$ & $487.837 \pm 51.097 \mathrm{a}$ \\
\hline & $\mathrm{Pb}\left(\mathrm{mg} \cdot \mathrm{kg}^{-1}\right)$ & $265.647 \pm 31.314 \mathrm{a}$ & $173.073 \pm 37.910 \mathrm{a}$ & $185.807 \pm 107.931 \mathrm{a}$ \\
\hline & $\mathrm{Zn}\left(\mathrm{mg} \cdot \mathrm{kg}^{-1}\right)$ & $105.606 \pm 10.795 \mathrm{a}$ & $72.359 \pm 10.873 b$ & $51.276 \pm 15.019 \mathrm{~b}$ \\
\hline \multirow[t]{3}{*}{ Litter } & TC_Litter $(\%)$ & $43.649 \pm 0.137 \mathrm{~A}$ & $43.115 \pm 0.102 \mathrm{AB}$ & $37.659 \pm 0.134 \mathrm{~B}$ \\
\hline & TN_Litter $(\%)$ & $1.269 \pm 0.041 \mathrm{~A}$ & $0.748 \pm 0.238 \mathrm{~B}$ & $1.172 \pm 0.072 \mathrm{AB}$ \\
\hline & $\mathrm{C} / \mathrm{N}$ Litter & $34.442 \pm 1.177 \mathrm{~B}$ & $62.567 \pm 19.759 \mathrm{~A}$ & $32.240 \pm 2.048 \mathrm{~B}$ \\
\hline
\end{tabular}

1 


\section{Table 2 (on next page)}

Enzyme activities of Imperata cylindrica litters over different years of phytoremediation.

Data are means \pm standard deviation. The different case letters indicate that the means are significantly different among different years of phytoremediation $(P<0.05)$. 


\begin{tabular}{lccc}
\hline Enzyme activities & S516 & S536 & S560 \\
\hline Cellulase $\left(\mathrm{mg} \cdot(\mathrm{g} \cdot 72 \mathrm{~h})^{-1}\right)$ & $0.849 \pm 0.068 \mathrm{a}$ & $0.774 \pm 0.040 \mathrm{a}$ & $0.458 \pm 0.228 \mathrm{~b}$ \\
Urease $\left(\mathrm{mg} \cdot(\mathrm{g} \cdot 24 \mathrm{~h})^{-1}\right)$ & $3.330 \pm 0.095 \mathrm{a}$ & $3.520 \pm 0.466 \mathrm{a}$ & $3.087 \pm 0.293 \mathrm{a}$ \\
Sucrase $\left(\mathrm{mg} \cdot(\mathrm{g} \cdot 24 \mathrm{~h})^{-1}\right)$ & $2.998 \pm 0.625 \mathrm{a}$ & $2.638 \pm 1.649 \mathrm{a}$ & $2.482 \pm 0.348 \mathrm{a}$ \\
Catalase $\left(\mathrm{mg} \cdot(\mathrm{g} \cdot 20 \mathrm{~min})^{-1}\right)$ & $5.271 \pm 0.701 \mathrm{a}$ & $3.191 \pm 0.193 \mathrm{~b}$ & $1.063 \pm 0.351 \mathrm{c}$ \\
Polyphenol oxidase $\left(\mathrm{mL} \cdot \mathrm{g}^{-1}\right)$ & $3.200 \pm 0.447 \mathrm{~b}$ & $5.300 \pm 0.837 \mathrm{a}$ & $3.800 \pm 0.837 \mathrm{~b}$ \\
\hline
\end{tabular}

1 